\title{
Perjanjian Kredit Yang Mencantumkan Kausula Asuransi Jiwa
}

\author{
Akhmad Faqih Mursid \\ Fakultas Hukum, Universitas Muhammadiyah Sorong \\ Email : Faqihmursid27@gmail.com
}

\begin{abstract}
Abstrak
Penelitian ini bertujuan untuk mengetahui, menganalisis dan menjelaskan penerapan hukum terhadap para pihak dengan dicantumkannya klausula asuransi jiwa dalam perjanjian kredit.

Berdasarkan penelitian dan Pembahasan, maka penulis menyimpulkan Dalam asuransi jiwa kita mengenal 3 (tiga) pihak yaitu penanggung, tertanggung (debitur yang menanggungkan jiwanya), penikmat (ahli wari atau yang diperjanjikan). Ketiga pihak bila disederhanakan lagi menjadi, debitur, kreditur, dan perusahaan asuransi. Asuransi jiwa yang merupakan salah satu contoh asuransi dengan biaya tertentu yang mana penggantian risiko tidak akan sesuai dengan risiko yang dialaminya.

Kematian merupakan evenemen dalam asuransi jiwa, yang menimbulkan hak dan kewajiban bagi para pihak. Pada umumnya ketika tertanggung meninggal dunia maka penanggung mempunyai kewajiban untuk memberikan ganti rugi kepada penikmat (ahli waris) kecuali diperjanjikan lain. Misalnya pihak debitur menyetujui klausula yang diberikan oleh pihak bank, berisikan kerja sama dengan pihak asuransi jiwa untuk menanggulangi risiko yang terjadi. Jadi dalam hal ini pihak bank bertindak sebagai pemegang polis (penerima) ganti kerugian.
\end{abstract}

Kata Kunci : Kredit Macet; Asuransi Jiwa Dan Perjanjian Kredit

\section{PENDAHULUAN}

Usaha-usaha yang dilakukan pemerintah dalam rangka mewujudkan cita-cita pembangunan antara lain memprioritaskan bidang ekonomi sebagai salah satu pergerak utama pembangunan. Dalam pelaksanaan pembangunan ekonomi dimaksud, salah satu caranya dengan memperlancar dan meningkatkan usaha-usaha pengerah dana dari masyarakat dengan menfaatkan potensi modal sebagai salah satu unsur pembanguna. Oleh karena itu diperlukan berbagai penyesuaian kebijakan dibidang ekonomi khususnya di sektor perbankan sehingga diharapkan akan dapat memperbaiki dan memperkokoh perekonomian nasional.

Lembaga perbankan mempunyai nilai strategis dalam kehidupan perekonomian suatu Negara, karena peranannya sebagai perantara pihak-pihak yang mempunyai kelebihan dana (surplus of fund) dengan pihak-pihak yang kekurangan dana (lack of fund). Dengan demikian perbankan akan bergerak dalam bidang perkreditan, dan berbagai jasa yang diberikan, bank melayani kebutuhan pembiayaan serta melancarkan mekanisme sistem pembayaran bagi semua sektor perekonomian.

Transaksi perbankan di bidang perkreditan memberikan peran bagi bank sebagai lembaga penyedia dana bagi debitur. bentuknya dapat berupa kredit, seperti kredit investasi, 
kredit modal kerja, kredit usaha kecil, dan jenis-jenis kredit lainya sesuai dengan kebutuhan debitur. hubungan antara bank dan debitur bersifat hubungan interpersonal yaitu bertumpu pada kepercayaan.

Seperti diketahui bersama bahwa dalam pemberian kredit tidak jarang menimbulkan masalah yang kompleks. Salah satunya adalah risiko utang tidak terbayarkan karena terjadinya bencana yang seringkali di luar kontrol itu adalah Debitur meninggal dunia atau cacat fisik; (1) Musnahnya record akunting sehingga kreditur tidak dapat membuktikan haknya terhadap debitur; (2) Kegagalan lembaga keuangan dimana dana-dana itu di depositokan; (3) Kegagalan suatu perusahaan yang insolvent membayar kredit bank; (4) Kegagalan pemilik rumah atau pemilik harta tetap lainnya membayar kredit bangunan karena insolvency; (5) Tindakan politik yang melarang debitur membayar utang-utangnya ke suatu negara lain; (6) Insolvency suatu perusahaan yang telah menerima kredit dagang.

Terhadap risiko-risiko yang mana sifatnya sangat merugikan, mendorong pihak bank bagaimana cara untuk menghilangkan atau minimal tidak mengurangi risiko yang mungkin timbul dalam setiap pemberian kredit. Salah satu caranya adalah dengan mengalihkan risiko tersebut kepada pihak lain yang memang dimungkinkan, baik dari segi yuridis maupun dari segi bisnis. Pihak lain yang dimaksud tersebut adalah perusahaan asuransi.

Perusahaan asuransi memberikan jaminan atas kelangsungan kehidupan bank dari risiko kerugian ekonomi, yakni risiko tidak dikembalikannya kredit yang telah dikucurkan kepada debiturnya. Implementasi hal tersebut oleh bank dalam memberikan fasilitas kredit, menyertakan klausula asuransi dalam setiap kredit perjanjian yang dibuatnya, misalnya klausula asuransi jiwa debitur.

Asuransi jiwa pada umumya hanya mengenal pihak penanggung (perusahaan asuransi), pihak tertanggung (orang yang jiwanya dipertanggungkan), dan pihak penerima manfaat/yang ditunjuk (pihak yang berhak menerima pembayaran uang santunan), biasanya ahli waris dari tertanggung. Namun dalam permasalahan ini perjanjian kredit diatas yang menjadi pihak penerimah manfaat adalah bank sedangkan debitur tetap sebagai pihak tertanggung.

Berdasarkan penjelasan di atas, maka yang menjadi permasalahan dalam penulisan adalah Bagaimana penerapan hukum terhadap para pihak dengan dicantumkannya klausula asuransi jiwa dalam perjanjian kredit?

\section{PEMBAHASAN}

\section{Tinjauan Yuridis Klausula Asuransi Jiwa Terhadap Perjanjian Kredit}


Undang-undang perbankan No. 10 Tahun 1998 Pasal 1 angka 11 menentukan bahwa kredit diberikan berdasarkan persetujuan atau kesepakatan pinjam meminjam antara bank dan pihak lain, namun undang-undang tersebut tidak menentukan lebih lanjut mengenai bagaimana bentuk persetujuan pinjam-meminjam tersebut. Dengan alasan keamanan dan kepastian hukum, dalam praktek lazimnya perjanjian kredit dituangkan dalam bentuk tertulis.

Perjanjian kredit yang dibuat dengan akta di bawah tangan maupun akta notaris, pada umumnya dibuat dengan bentuk perjanjian baku yaitu dengan cara kedua belah pihak (pihak bank dan pihak nasabah) menandatangani suatu perjanjian yang sebelumnya telah dipersiapkan isi atau klausula-klausulanya oleh bank dalam suatu formulir tercetak. Dalam hal perjanjian kredit dibuat dengan akta notaris, maka bank akan meminta notaris berpedoman kepada model perjanjian kredit dari bank yang bersangkutan. Notaris diminta untuk memedomani klausula-klausula dari model perjanjian kredit bank yang bersangkutan .

Perjanjian kredit bank, memuat serangkaian klausula, dimana sebagian besar dari klausula tersebut merupakan upaya untuk melindungi pihak kreditur dalam pemberian kredit. Klausula merupakan serangkaian persyaratan yang diformulasikan dalam upaya pemberian kredit ditinjau dari aspek finansial dan hukum.

Dari aspek finansial, klausula melindungi kreditur agar dapat menuntut atau menarik kembali dana yang telah diberikan kepada debitur dalam posisi yang menguntungkan bagi kreditur apabila kondisi debitur tidak sesuai yang diperjanjikan. Sedangkan dari aspek hukum, klausula merupakan sarana untuk melakukan penegakkan hukum agar debitur dapat mematuhi subtansi yang telah disepakati di dalam perjanjian kredit.

Menurut Ch. Gatot Wardoyo ada beberapa klausula yang selalu ada dan perlu dicantumkan dalam setiap perjanjian kredit, yaitu diantaranya: Klausula asuransi (insurance clause). Klausula ini bertujuan untuk mengalihkan risiko yang mungkin terjadi, baik atas barang agunan maupun atas kreditnya sendiri. Adapun materinya perlu memuat mengenai maskapai asuransi yang ditunjuk, premi asuransi, keharusan polis asuransi untuk disimpan dibank, dan sebagainya.

Untuk mengantisipasi kerugian yang akan dialami oleh pihak bank, maka pihak bank akan melakukan kerjasama dengan pihak asuransi, tentunya dengan klausula-klausula yang telah dibuat oleh pihak bank, yang mengikut sertakan pihak asuransi. klausula dalam asuransi diperbolehkan selama klausula tidak bertentangan dengan peraturan-peraturan dan kepentingan umum.

Perjanjian asuransi menciptakan tatanan hubungan hukum antara para pihak. Tatanan hukum ini melahirkan hak dan kewajiban. Menurut Sudikno Mertokusumo, tatanan yang 
diciptakan oleh hukum baru menjadi kenyataan apabila kepada subyek hukum diberi hak dan dibebani kewajiban. Setiap hubungan hukum yang diciptakan oleh hukum selalu mempunyai dua segi yang isinya disatu pihak "hak" sedangkan dipihak lain "kewajiban". Tidak ada hak tanpa kewajiban, sebaliknya tidak ada kewajiban tanpa hak. Begitupula halnya yang terjadi dalam hubungan hukum asuransi, penanggung menerima pengalihan risiko dari tertanggung dan tertanggung membayar sejumlah premi sebagai imbalannya. Apabila premi tidak dibayar asuransi dapat dibatalkan dan setidak-tidaknya asuransi tidak berjalan sebagaimana diharapkan.

Mengenai defenisi dari asuransi atau pertanggungan ini, Emmy Pangaribuan Simanjuntak memberikan 2 pengertian, yakni; (1) Pertanggunga kerugian di dalam pengertian yang murni harus mengandung suatu tujuan bahwa kerugian yang sungguhsungguh diderita oleh pihak tertanggung akan diganti oleh pihak penanggung.; (2) Pertanggungan sejumlah uang (sommen verzekering) merupakan pertanggungan dimana penggantian kerugian yang diberikan oleh penanggung sebenarnya tidak dapat dikatakan sebagai suatu ganti rugi oleh karena orang yang menerima ganti rugi itu tidak menerima ganti rugi yang sungguh-sungguh sesuai dengan kerugian yang dideritanya. Ganti rugi yang diterimanya itu sebenarnya adalah hasil penentuan sejumlah uang tertentu yang telah disepakati oleh pihak-pihak.

Pertangungan sejumlah uang atau asuransi sejumlah uang termaksud didalamnya asuransi jiwa, ketika terjadi kerugian maka sesungguhnya ganti kerugian yang didapatkan tidak sesuai dengan kerugian yang di derita oleh tertanggung. Pembayaran ganti kerugian berdasarkan kesepakatan yang telah ditentukan.

Menurut Purwosutjipto, asuransi jiwa merupakan perjanjian timbal balik antara penutup (pengambil) asuransi dengan penanggung, dengan mana penutup (pengambil) asuransi mengikatkan diri selama jalannya pertanggungan membayar uang premi kepada penanggung, sedangkan penanggung sebagai akibat langsung dari meninggalnya orang yang jiwanya dipertanggungkan atau telah lampaunya suatu jangka waktu yang diperjanjikan, mengikatkan diri untuk membayar sejumlah uang tertentu kepada orang yang ditunjuk oleh penutup (pengambil) asuransi sebagai penikmatnya.

Asuransi jiwa, disamping berfungsi sebagai pelimpahan resiko, secara ekonomis dapat pula berfungsi sebagai tabungan, yaitu apabila sampai batas waktu perjanjian tidak terjadi peristiwa kematian yang merupakan salah satu faktor penentu, untuk pelaksanaan perjanjian asuransi/pertanggungan. 
Perjanjian asuransi/ pertanggungan jiwa pada asasnya dapat terjadi atas dasar adanya kata sepakat para pihak. Kata sepakat dapat dimulai dari pihak tertanggung dan memang biasanya dimulai oleh adanya prakarsa dari calon tertanggung, yang menyatakan kehendaknya akan menutup perjanjian asuransi/pertanggungan jiwa dengan pihak penanggung.

Asuransi jiwa berakhir karena beberapa hal yaitu: pertama, karena terjadinya evenemen (peristiwa tidak tentu). Satu-satunya evenemen yang menjadi beban penanggung adalah meninggalnya tertanggung. Apabila dalam jangka waktu yang diperjanjikan terjadi peristiwa meninggalnya tertanggung, maka penanggung berkewajiban membayar uang santunan kepada penikmat yang ditunjuk oleh tertanggung atau kepada ahli warisnya. Sejak penanggung melunasi uang santunan tersebut, sejak itu pula asuransi jiwa berakhir. Kedua, asuransi jiwa berakhir karena jangka waktunya berakhir. Apabila jangka waktu berlakunya asuransi jiwa itu habis tanpa terjadi evenemen, maka beban risiko penanggung berakhir. Akan tetapi, dalam perjanjian ditentukan bahwa penanggung akan mengembalikan sejumlah uang kepada tertanggung apabila sampai jangka waktu asuransi habis tidak terjadi evenemen. Dengan kata lain asuransi jiwa berakhir sejak jangka waktu asuransi habis diikuti dengan pengembalian sejumlah uang kepada tertanggung. Ketiga, karena asuransi jiwa gugur. Ketentuan Pasal 306 KUHD menegaskan bahwa terhadap orang yang diasuransikan jiwanya, pada saat diadakan asuransi ternyata sudah meninggal, maka asuransi tersebut gugur meskipun sebenarnya tertanggung tidak mengetahui kematian tersebut, kecuali jika diperjanjikan lain. Lebih lanjut bunyi Pasal 307 KUHD juga menentukan bahwa terdapat orang yang mengasuransikan jiwanya melakukan tindakan bunuh diri atau dijatuhi hukuman mati, maka asuransi jiwa tersebut menjadi gugur. Namun terhadap dua ketentuan ini para pakar berpendapat bahwa masih bisa dilakukan penyimpangan apabila para pihak menghendaki. Keempat, karena asuransi dibatalkan sebelum jangka waktunya berakhir. Hal ini dapat saja terjadi karena tertanggung tidak melanjutkan pembayaran premi sesuai dengan perjanjian atau karena permohonan tertanggung sendiri. Permasalahan yang timbul dari pembatalan tersebut penyelesaianya bergantung pula pada kesepakatan pihak-pihak yang dicantumkan dalam polis.

Dalam asuransi jiwa, satu-satunya evenemen yang menjadi beban risiko penanggung adalah meninggalnya tertanggung. Terhadap evenemen inilah diadakan asuransi jiwa antara tertanggung dan penanggung. Apabila dalam jangka waktu yang diperjanjikan terjadi peristiwa meninggalnya tertanggung, maka penanggung berkewajiban membayar uang santunan kepada penikmat yang ditunjuk oleh tertanggung, atau kepada ahli warisnya. Sejak 
penanggung melunasi pembayaran uang santunan tersebut, sejak itu pula asuransi jiwa berakhir.

Dalam asuransi jiwa yang menjadi pihak yaitu penanggung, tertanggung yang melakukan perjanjian asuransi, dan perusahaan asuransi. Asuransi jiwa debitur dalam pemberian kredit dapat menimbulkan hubungan hukum 3 (tiga) pihak yaitu bank, nasabah debitur dan perusahaan asuransi. Debitur menutup perjanjian asuransi atas jiwanya berdasarkan kewajibannya terhadap bank untuk melunasi kredit yang telah diterimahnya. Kewajiban ini lahir berdasarkan perjanjian yang telah ditandatangani antara debitur dan bank, yaitu perjanjian kredit.

Debitur berkewajiban untuk mengembalikan semua kredit yang telah diperolehnya dari bank sesuai jangka waktu yang sudah ditentukan dalam perjanjian kredit. Risiko atas kredit karena terjadinya sesuatu yang menimpa debitur (meninggal dunia) sehingga mengakibatkan dirinya tidak sanggup untuk membayar cicilan kredit, merupakan tanggung jawab debitur selaku pihak yang berkewajiban melunasi kredit yang telah diterimahnya dari bank. Oleh karena itu untuk mengatasi risiko tersebut maka kreditur mengalihkannya kepada pihak perusahaan asuransi selaku penanggung.

Dengan demikian apabila terjadi peristiwa meninggalnya debitur yang menyebabkan kerugian bagi bank karena terjadinya kemacetan pembayaran kredit, pihak asuransi akan mengganti kerugian tersebut kepada bank. Bank selaku pihak yang dirugikan sudah tentu berhak atas suatu ganti kerugian yang diberikan perusahaan asuransi. Besarnya ganti rugi yang diberikan kepada bank adalah hanya sebesar sisa utang debitur yang belum terlunasi, selanjutnya sisa dari pembayaran tersebut lazimnya dalam asuransi jiwa harus diberikan kepada penikmat (biasanya ahli waris debitu). Hak bank ini dinyatakan dalam perjanjian asuransi jiwa debitur antara debitur dengan pihak asuransi bahwa yang akan menerima ganti rugi seandainya peristiwa yang diasuransikan benar-benar terjadi. Hal ini di dasarkan atas pertimbangan bahwa yang berkepentingan atas meninggalnya debitur yang menjadi obyek asuransi adalah bank. Pasal 250 KUHD menentukan pihak yang berhak menerima ganti kerugian adalah pihak yang berkepentingan.

Hubungan hukum yang terjadi antara perusahaan asuransi dengan bank adalah pemenuhan prestasi sebagai janji untuk kepentingan pihak ketiga yang dituangkan dalam perjanjian antara debitur dengan perusahaan asuransi. Debitur menunjuk bank sebagai pihak yang menerima ganti kerugian. Mengenai janji untuk pihak ketiga ini seperti yang ditentukan dalam pasal 1317 KUHPerdata bahwa para pihak dapat mengadakan perjanjian dengan janji 
bahwa salah satu pihak dibebankan kewajiban untuk melakukan prestasi kepada pihak ketiga yang ditunjuk dalam perjanjian tersebut.

Asuransi jiwa dapat pula diadakan untuk pihak ketiga dan ini harus dicantumkan dalam polis. Menurut teori kepentingan pihak ketiga (the third party interest theory), dalam asuransi jiwa pihak ketiga yang berkepentingan itu disebut penikmat. Penikmat itu dapat berupa orang yang ditunjuk oleh tertanggung atau ahli waris tertanggung. Munculnya penikmat ini apabila terjadi evenemen meninggalnya tertanggung. Dalam hal ini, tertanggung yang meninggal itu tidak mungkin dapat menikmati santunan, tetapi penikmat yang ditunjuk atau ahli waris tertanggunglah sebagai pihak yang berhak menerima santunan. Akan tetapi dalam hal evenemen meninggalnya tertanggung tidak terjadi, maka tertanggung sendiri yang berkedudukan sebagai penikmat karena dia sendiri masih hidup dan berhak menerima pengembalian sejumlah uang yang dibayar oleh penanggung.

Bila dikaitkan dengan asuransi jiwa debitur yang lahir sebagai bentuk proteksi kredit yang telah dikuncurkan pihak bank kepada debiturnya, maka yang menjadi penikmat adalah bank bila mana debitur meninggal dunia. Perusahan asuransi akan membayarkan sejumlah uang kepada bank untuk melunasi kredit debitur yang diasuransikan jiwanya.

Sri Redjeki Hartono menyatakan bahwa dalam asuransi jiwa, secara nyata posisi penanggung adalah tetap, ia selalu sebagai pihak yang menerimah dan mengambil alih risiko dari pihak lain, apakah dari pengambil asuransian, tertanggung atau pihak lain yang berkepentingan. Adapun yang berubah dan dapat menyangkut pihak ketiga adalah posisi dari pengambil asuransi atau yang berkepentingan. Kemungkinan -kemungkinan bergesernya posisi pihak-pihak dalam perjanjian asuransi jiwa adalah sebagai berikut; (1)Pengambil Asuransi/Pemegang Polis sama dengan Tertanggung sama dengan Tertunjuk. Ini dapat terjadi terhadap seseorang yang menutup perjanjian asuransi untuk dirinya sendiri atas jiwanya sendiri dan akan diterimahnya sendiri setelah jangka waktu perjanjian berakhir.; (2) Pengambil Asuransi/Pemegang Polis sama dengan Tertanggung, tetapi Tertunjuk tidak sama. Hal ini terjadi misalnya pada seseorang yang mengasuransikan jiwanya untuk kepentingan masa depan keluarganya.; (3) Pengambil Asuransi/ Pemegang Polis tidak sama dengan Tertanggung dan tidak sama pula dengan Tertunjuk. Hal ini dapat terjadi andaikata seorang majikan mengambil prakarsa menutup perjanjian asuransi jiwa dengan penanggung, dimana ia membayar premi, tertanggungnya adalah karyawan, artinya pembayaran sejumlah uang yang diperjanjikan itu digantungkan pada jiwa si karyawan, sedangkan nanti pada masa akhir perjanjian yang menerima pembayaran sejumlah uang dari penanggung adalah ahli waris/keluarga dari karyawan tersebut. 
Dari ketiga kemungkinan tersebut diatas, nampak bahwa sesungguhnya polis dari pihak yang melimpahkan risiko itu tetap merupakan pihak yang berkepentingan dalam perjanjian asuransi.

\section{SIMPULAN}

Dalam asuransi jiwa kita mengenal 3 (tiga) pihak yaitu penanggung, tertanggung (debitur yang menanggungkan jiwanya), penikmat (ahli wari atau yang diperjanjikan). Ketiga pihak bila disederhanakan lagi menjadi, debitur, kreditur, dan perusahaan asuransi. Asuransi jiwa yang merupakan salah satu contoh asuransi dengan biaya tertentu yang mana penggantian risiko tidak akan sesuai dengan risiko yang dialaminya.

Kematian merupakan evenemen dalam asuransi jiwa, yang menimbulkan hak dan kewajiban bagi para pihak. Pada umumnya ketika tertanggung meninggal dunia maka penanggung mempunyai kewajiban untuk memberikan ganti rugi kepada penikmat (ahli waris) kecuali diperjanjikan lain. Misalnya pihak debitur menyetujui klausula yang diberikan oleh pihak bank, berisikan kerja sama dengan pihak asuransi jiwa untuk menanggulangi risiko yang terjadi. Jadi dalam hal ini pihak bank bertindak sebagai pemegang polis (penerima) ganti kerugian.

\section{DAFTAR PUSTAKA}

Abdulkadir Muhammad, 2011, Hukum Asuransi Indonesia, Cetakan Kelima, Citra Aditya Bakti, Bandung, hlm 195-196

A. Hasymi Ali, 1993, Bidang Usaha Asuransi, Bumi Aksara, Jakarta, hlm. 67.

Emmy Pangaribuan Simanjuntak, 1990, Hukum Pertanggungan (pokok-pokok pertanggungan kerugian, kebakaran dan jiwa), Cetakan Kesepuluh, Seksi Hukum Dagang Fakultas Hukum Universitas Gadjah mada, yogyakarta, hlm.8-9.

Man Suparman Sastrawidjaja, Endang, 2004, Hukum Asuransi (Perlindungan Tertanggung, Asuransi Doposito, usaha perasuransian), Alumni, Bandung, hlm 199

Muhamad Djumhan, 2000, Hukum Perbankan Di Indonesia, Citra Aditya Bakti, Bandung, hlm ix.ibid, hlm. 365.Sutan Remy Sjahdeini,1997, kredit sindikasi. Proses pembentukan dan Aspek Hukum, Pustaka Utama Grafiti jakarta. Hal 182

Sudikno Mertokusumo, 2008, Mengenal Hukum (Suatu Pengantar), cetakan keempat, Liberty, Yogyakarta.hlm.41.

Sri Redjeki Hartono,1985, Asuransi dan Hukum Asuransi di Indonesia, Cetakan Pertama, Ikip Semarang Press, Semarang, hlm. 164-165. 